\title{
Máscaras Iluministas - os USOS RETóRICOS DO SELVAGEM
}

\section{Samuel Titan Jr.*}

\begin{abstract}
Resumo: $\mathrm{O}$ artigo trata da incorporação do selvagem à filosofia e à literatura francesas a partir da análise de um conto de Voltaire. Procura-se mostrar a apropriação da figura não-civilizada como porta-voz de ideais iluministas de razão e sociabilidade.
\end{abstract}

Unitermos: Homem Selvagem - Iluminismo - Voltaire - Literatura e Filosofia Francesas.

\begin{abstract}
Through an analysis of Voltaire's short story L'Ingénu, this article traces the incorporation of the savage man into French literature and philosophy. We try to show how the non-civilized figure was appropriated as a fictional spokesman of Enlightenment ideals of reason and social intercourse.
\end{abstract}

Keywords: Savage Man - Enlightenment - Voltaire - French Literature and Philosophy.

Publicado pela primeira vez em 1767 , portanto séculos depois do desembarque de São Dunstan na baía de Saint-Malo e da fundação do Priorado da Montanha, O Ingênuo de Voltaire narra a chegada àquele mesmo porto, a 15 de julho de 1689 , de uma embarcação inglesa trazendo a bordo, entre mercadorias britânicas, um selvagem da América do Norte, um hurão cognominado "o Ingênuo" devido a seu hábito de sempre dizer o que pensa e fazer o que quer. Bem recebido pela sociedade local, e logo reconhecido como sobrinho de seus dois anfitriões - o que lhe confere o privilégio de uma origem baixo-bretã -, o Ingênuo começa a desconcertar a gente com a mania inoportuna de nutrir dúvidas sensatas e levantar objeções razoáveis: sua conversão exige algum esforço, o batismo é algo conturbado. A certa altura, esquecendose dos encantos selvagens de Mlle. Abacaba e a despeito das graças inegáveis de Mlle. de Kerkabon - que valem todo um priorado -, o hurão se apaixona pela formosa Mlle. St. Yves. Surgem então alguns obstáculos à união: a moça insiste em pedir o consentimento dos parentes, o que parece estranho ao hurão; ela mesma é madrinha de batismo do Ingênuo, e "é um pecado terrível para uma madrinha tomar assim a mão de seu afilhado" [338], o que torna necessária uma per-

\footnotetext{
* O autor agradece ao Prof. Luiz Fernando Franklin de Matos, do Departamento de Filosofia da USP, pela leitura cuidadosa e pelas várias sugestões bibliográficas. As citações d'O Ingênuo, em negrito e entre colchetes, referem-se à edição de René Pomeau - Romans et Contes (Paris: Flammarion, 1966); as traduções são todas minhas.
} 
missão do Papa. Indignado, o selvagem parte em direção à Abadia de St.Yves, disposto a esposar sua amada à maneira de sua terra; educada na bienséance e na honnêteté, ela resiste. Lemos então o trecho seguinte, tirado ao capítulo VI [339-340]:

\begin{abstract}
"O Ingênuo não queria saber de conversa; achava todos esses modos extremamente impertinentes. 'Não era assim que agia Mlle. Abacaba, minha primeira noiva; não tendes probidade alguma; prometestes-me casamento, e agora não quereis casar-vos: é faltar às leis primeiras da honradez; eu vos ensinarei a manter a palavra, e vos reconduzirei ao caminho da virtude.'

O Ingênuo possuía uma virtude máscula e intrépida, digna de seu patrono Hércules, cujo nome recebera no batismo; estava a ponto de exercê-la em toda sua extensão quando, aos gritos lancinantes da mais discretamente virtuosa das donzelas, acorreu o sábio abade de St.Yves, com sua governanta, um velho doméstico devoto e um padre da paróquia. Essa visão moderou a coragem do atacante. '- Ah, meu Deus! Meu caro vizinho,' disse o abade - 'que estás a fazer?' '-Meu dever;' - replicou o jovem - 'cumpro sempre minhas promessas, que são sagradas.' Mlle. de St.Yves recompôs-se, enrubescida. Conduziram o Ingênuo a um outro aposento. $\mathrm{O}$ abade fez-lhe ver a enormidade do ato. O Ingênuo defendeu-se com os privilégios da lei natural, que conhecia perfeitamente. $\mathrm{O}$ abade quis provar que a lei positiva devia ter precedência, e que sem convenções acertadas entre os homens, a lei natural seria pouco mais que uma pilhagem natural. 'Há que existir' - dizia ele - 'notários, padres, testemunhas, contratos, dispensas.' O Ingênuo respondeu-lhe com a reflexão que os selvagens têm sempre feito: '- Sois decerto gente bem desonesta, se são necessárias tantas precauções entre vós."
\end{abstract}

A passagem citada exibe todos os traços fundamentais não somente d'O Ingênuo, como de todos os contos filosóficos de Voltaire: humor instantâneo, sucessão vertiginosa de acontecimentos, conjunções dispa- ratadas de noções e eventos, erotismo flutuante mas jamais voyeurista. A cena do "casamento" serve-se em larga medida de um artifício básico da comédia (WATT 1990, p. 288): o engano de dois personagens (ou mais) quanto às intenções alheias, sem que, além de certo pandemônio, quaisquer conseqüências sérias e irreversíveis devam resultar daí. No caso, a graça da cena depende das interpretações diversas que Mlle. St.Yves (a França) e o Ingênuo (a Hurônia) dão à idéia de casamento. Essa confusão é a matriz de outras, que atravessam todo o texto na forma de lugares-comuns que o Ingênuo, o abade e o narrador vão acumulando ("modos impertinentes", "probidade alguma", "faltar às leis primeiras da honradez", "manter a palavra", "reconduzir ao caminho da virtude", "meu dever", "a enormidade do ato", e finalmente o par conceitual "lei natural / lei positiva"). O Ingênuo domina todas as fórmulas verbais do código moral civilizado, e enfileira-as com segurança invejável, haja vista a ausência de quaisquer conectivos em sua argumentação quase imperativa: "não era assim que fazia", "não tendes", "prometestes", "eu vos ensinarei ... reconduzirei"; mas ele as utiliza todas fora do contexto habitual, e justifica a violação de Mlle. St.Yves à luz do dever, das promessas feitas e das leis da honradez. Rimos de sua falta de jeito, mas rimos também do embaraço e artificialismo dos outros: afinal, poucas perguntas poderiam ser mais ingênuas, ridículas e deslocadas do que "meu caro vizinho, que estás a fazer?"

Nosso riso é aliás sancionado pelo narrador, que já nos mostrou o interesse que Mlle. St.Yves, "a mais discretamente virtuosa das donzelas", dèmonstra pelas partes viris de Hércules, por ocasião de seu batismo: "Ele insistia sempre sobre o eunuco da rainha Candace; e muito embora a senhorita sua tia e Mlle. St.Yves, que o haviam observado por entre os juncos, tivessem o direito de lhe dizer que não lhe cabia citar tal espécie de homens, elas não o fizeram, tão gran- 
de era sua discrição" [335]; uma vez dado o consentimento do Ingênuo em se deixar batizar na igreja - obtido com a ambígua pergunta: "Não faríeis nada por mim?" -, Mlle. St.Yves se regozija: "Ela percebeu seu triunfo; mas não o percebia ainda em toda sua extensão." [335 - grifos meus]. Mas sua hora não tarda: "O Ingênuo possuía uma virtude máscula e intrépida", e não poderia deixar de tê-la assim, dadas sua educação ameríndia e a etimologia de virtude (virtus, vir), que o impelem a "exercê-la em toda sua extensão", causa sem dúvida da "enormidade do ato" a que se refere o sábio abade. E a honradez feminina de Mlle. St.Yves faz-lhe provavelmente bom par, já que não sabemos com certeza se seus "gritos lancinantes" e o vermelho das faces se referem à ousadia do Ingênuo ou à chegada do irmão-abade. Num dos ensaios de Mimesis, Auerbach anotava a respeito da comédie larmoyante do século XVIII: "ao vício trivial corresponde também uma noção igualmente trivial da virtude; ela está total e integralmente voltada para a vida sexual, para a sua ordem ou desordem, e em consequêencia disso, inteiramente erotizada; o que se entende aqui por virtude não é sequer concebível sem o aparato das sensações eróticas" (AUERBACH 1988, p. 375). O mesmo vale para Voltaire: enquanto peça romanesca, a virtude corresponde a um "obstáculo" propiciador de aventuras, algo que se invoca tão-somente para se contornar; ela é da ordem dos estímulos eróticos, que supostamente formariam seu pólo oposto.

Não são apenas as trapalhadas verbais que dão o tom do conto. Falamos do ritmo acelerado e do gosto pelas justaposições e definições sumárias, e de fato passamos a vista, no decorrer de poucas páginas, sobre o eunuco de uma rainha bíblica, uma discussão teológico-filosófica sobre as leis natural e positiva, uma polêmica sobre a confissão, uma anedota sobre os dotes de Hércules (o grego), o avanço sobre Mlle. St.Yves e a necessidade de uma autorização papal; este último, aliás, não é mais que "um homem que meora para os lados do Mediterrâneo, a quatrocentas léguas daqui, e cuja língua não entendo!" [338]. Mais que simples sucessão, há uma espécie de motivação disparatada dos eventos e argumentos: no trecho citado, não é a conquista da América que motiva a discussão sobre a superioridade da lei positiva, mas sim a honra da cobiçada donzela. Voltaire está longe de encenar um debate alegórico entre o Selvagem e o Europeu; seu intuito e seu método permanecem cômicos, convidando-nos a entender "desejos carnais" onde se diz "lei natural", e "convencionalismo provinciano e civilizado" no lugar de "lei positiva". Em certa passagem de Anatomia da Crítica, Northrop Frye via o embate entre Sócrates e Trasímaco (na República) como similar ao confronto do eíron e do alazón de uma comédia típica (FRYE s.d., p. 181), num raciocínio que podemos estender ao symposion paródico entre o Ingênuo e o sage abbé - contanto que desçamos um degrau mais na escala do cômico. Quando o Ingênuo chega a sua conclusão sobre a desonestidade das gentes civilizadas, verdadeira razão de ser de toda a parafernália jurídico-estatal, não há quem possa negar-lhe certo bom-senso; é possível mesmo encontrar uma passagem análoga em Rousseau: mais débeis que as paixões, as leis em geral controlam os homens, sem modificá-los; seria fácil provar que um governo que, sem se corromper ou degradar, funcionasse sempre de modo íntegro, segundo o fim de sua constituição, teria sido instituído necessariamente, e que um país onde ninguém eludisse as leis nem abusasse da magistratura, não teria necessidade nem de magistrados nem de lei (ROUSSEAU 1964, p. 188); mas já que em Voltaire tudo se dá em tom menor, ninguém sairia a queimar registros, como durante a Revolução.

Este artifício não é exclusivo d'O Ingênuo, tal como não se restringe apenas à obra narrativa de Voltaire. Analisando trechos do 
Cândido, Auerbach notava o ritmo acelerado e o gosto por séries causais paródicas, que uniam extremos humoristicamente díspares (AUERBACH 1988, p. 383); e lendo um trecho das Cartas Inglesas (carta VI), via a mesma técnica de antíteses ou justaposições sumárias e deslocamento de contexto: ela consiste em "iluminar excessivamente uma pequena parte de um grande e complexo contexto, deixando na escuridão todo o restante que pudesse explicar ou ordenar aquela parte, e que talvez servisse como contrapeso daquilo que é salientado" (AUERBACH 1988 , p. 378). No texto analisado por Auerbach - uma descrição da Bolsa londrina -, tratava-se de fazer o elogio do "suave comércio" que une os homens às custas do fanatismo religioso que os separa; para isso bastava a Voltaire definir literalmente os dogmas e cerimoniais de cada seita (como o Ingênuo faz com o Papa ou com os conventos [341]), sem mencionar-lhes a razão de ser, contrapondo o pretenso universalismo de cada religião à pluralidade de crenças e ao particularismo dos ritos, para finalmente sobrepor-lhes a "comunhão" pacífica dos homens de comércio. O mesmo tema e a mesma técnica ocorrem tanto em nosso texto (ver o capítulo VIII) como em Cândido, nos dois casos por ocasião de encontros com huguenotes e anabatistas, onde se percebe a inanidade de um conflito religioso que rouba ao país cidadãos honestos e laboriosos.

Falamos do humor instantâneo do conto de Voltaire, e vimos em nossa passagem que ele está ligado à capacidade do leitor de perceber a incongruência das situações. Tão fácil é a operação de inversão irônica do sentido, que esse segundo sentido parece desde sempre dado na superfície do texto; ora, fosse este o caso, não haveria qualquer inversão a efetuar e nenhum prazer em vê-la consumada. Por mais cristalino que seja o texto voltaireano, o leitor que tente refazer seus próprios passos deve reconhecer-lhe um mínimo de intransparência inicial, ao lado da meridiana certeza a respeito do sentido da ironia. Isso implica que o leitor-destinatário de L'Ingénu não deva absolutamente ser ingênuo: ele deve ter perfeita ciência e controle completo das convenções e maneirismos sociais, mas também daquilo que elas mascaram. Por um lado, ele deve saber que o Papa não é apenas um personagem que mora na longínqua Roma, e sim o líder máximo da Cristandade; por outro, espera-se que ele perceba o absurdo de viajar quatrocentas léguas a fim de pedir o consentimento de um senhor desconhecido de todos. Wayne Booth caracterizou a possibilidade desse encontro entre autor e leitor como stable irony, aquela forma de discurso irônico ligada à inversão do sentido manifesto, em contextos que proporcionam aos participantes a certeza de que: a) o sentido manifesto deve ser rejeitado; b) o sentido verdadeiro deve ser procurado em uma direção, determinada pelo conhecimento, por parte do leitor-ouvinte, das intenções do autor-emissor (BOOTH 1974, pp. 10-12). Esse é um resultado atingido em cooperação: "Quando começo a pensar sobre esse (...) ato de reconstrução, percebo que ele arremata uma conquista comum bem mais impressionante do que muitas análises têm reconhecido. Afinal de contas, suas complexidades são compartilhadas: a coisa não funciona a não ser que ambas as partes da aliança estejam seguras de que estão movendo-se na mesma direção. O impressionante nisso tudo não está em que as coisas freqüentemente dêem errado - mas sim em que alguma vez dêem certo. (...) mesmo a mais simplória das ironias, quando funciona, revela em ambos os participantes uma espécie de encontro com a mente alheia (...)" (BOOTH 1974, p. 13). Retornando a Voltaire, cujo Cândido serve de exemplo a Booth, digamos, então, que um leitor escravizado pelas convenções sociais só poderia reagir às confusões do Ingênuo ou bem com a estupefação de seus parentes, ou bem com o riso superior de quem, hábil nos rapapés, ri da maladresse do 
selvagem. Aparentemente bom leitor de ironias, este último estaria confundindo por larga margem as intenções de Voltaire: sabemos que devemos e podemos dar um passo a mais em nossa leitura irônica, e assim também rir da sociedade baixo-bretã, desprezar o fanatismo jesuíta e jansenista, a ritualística religiosa e o cerimonial da corte. Nosso riso deve ir além da mera satisfação de um sentimento de superioridade bem-estabelecida; como escreveria Schiller, fora do contexto cômico e falando de nossa atitude frente à ingenuidade infantil (mas também frente aos "costumes da gente do campo e do mundo primitivo"): "É erro acreditar que a mera representação do desamparo seja aquilo que, em certos momentos, nos detém com tanta comoção junto às crianças. Este pode ser talvez o caso daqueles que, diante da fraqueza, não costumam sentir senão a própria superioridade. Mas o sentimento de que falo (...) é antes humilhante do que favorável ao amor-próprio (...)" (SCHILLER 1991, p.45).

Voltaire escreve, então, para os já iniciados, e estes sabem que Voltaire escreve para eles. Já mencionamos o aval implícito do narrador a nosso riso irônico; podemos compreendê-lo melhor agora. Naquela série de lugares-comuns e desentendimentos do nosso trecho reconhecemos um efeito da ingenuidade de Hércules e, simultaneamente, a obra de um "deus-relojoeiro" (STAROBINSKI 1966, p. 282) que se encarrega de acumulá-los todos e garantir o efeito cômico. Talvez o autor tivesse em mente o mesmo tipo de audiência simpatizante que, vinte anos antes, em 1747, ouvira a leitura de Zadig e Memnon nos salões da duquesa du Maine em Sceaux, onde o escritor se refugiara da perseguição cortesã. Isso promove uma curiosa aliança entre o autor-hurão e o leitor: o primeiro serve de alter ego textual deste último - senhor ou dama cultivados! O selvagem $n u$ de corpo e alma é, portanto, uma máscara retórica do homem de espírito, que pode assim gozar vicariamente os privi- légios da selvageria sem comprometer sua posição social tão mantida a tão duras penas; sua ignorância é, ao fim e ao cabo, uma simulação, um disfarce para colocar perguntas sobre os fundamentos racionais do hábito (que não os tem) ou sobre a autenticidade (duvidosa) da religião revelada. O objetivo, claro, é pôr em embaraço os simplórios, os dogmáticos e os finórios, levá-los todos à situação do pobre jansenista: "Tal ingenuidade causou um belo embaraço ao bom homem; sentia que eram vãos seus esforços por sair desse lodaçal; e amontoava tantas palavras que pareciam fazer sentido e que não tinham nenhum (...) que o Ingênuo se apiedou dele" [351]. Mas Voltaire não chega nunca a mostrar o hurão como representante de uma civilização inteiramente diversa e porventura incomensurável, até porque o herói é de fato baixo-bretão: basta que ele contribua para o conto com seu olhar ligeiramente estrangeiro para que suas pseudo-origens selvagens tenham cumprido seu papel. Como o selvagem responde ao bacharel nos Conversações de um Selvagem e de um Bacharel, publicados em 1765: na América é tudo como entre vós, a não ser por algumas cerimônias (VOLTAIRE 1939, 96).

Não é difícil encontrar as marcas do caráter factício de Hércules. De um verdadeiro ingênuo se espera que também sua ingenuidade não lhe seja conhecida, enquanto que o nosso parece ter perfeita consciência de sua condição, e talvez mesmo de sua função na história: "Sempre me chamaram 'o Ingênuo' (...) porque sempre digo ingenuamente o que penso, assim como faço tudo o que quero" [325]; "Meus compatriotas da América não teriam jamais me tratado com a barbárie de que sofro agora - sequer podem imaginála. Chamam-nos selvagens; são gente bem grosseira, e os homens desta terra aqui são patifes refinados" [349]; "Falei conforme à natureza; pode ser que em mim a natureza seja bastante imperfeita; mas pode ser também que por vezes ela seja pouco consultada 
pela maioria dos homens" [356]. O Ingênuo conhece todos os termos do debate pelo qual a Europa tenta se avir com o impacto das grandes descobertas: natureza, razão, senso comum, barbárie, civilização, etc. Essas passagens são piscadelas que o autor dirige a seu leitor: ambos têm perfeita consciência do jogo de disfarces, mas não vêem ainda razão para interromper a brincadeira. Tanta clarividência (européia) sobre si mesmo rouba ao Ingênuo qualquer moto próprio, qualquer surpresa cultural realmente inesperada para o leitor cultivado, o cidadão - ou melhor, o cortesão - iluminista médio francês. Tudo isso se vê confirmado na grande heure creuse narrativa (capítulos X-XII e XIV) da estadia na prisão: cessam as aventuras do Ingênuo para que ele possa absorver o cânon mínimo do Iluminismo de salão, adquira suas luzes científicas e saiba apreciar uma boa tragédia (gênero dos mais convencionalizados na França dos séculos XVII-XVIII). Nesse episódio, o Ingênuo realiza o que seu bomsenso nato já prometia: o gozo das promessas da civilização libertadas da ganga de artificialismo e de fanatismo que as sufocam. Como última contraprova da "inautenticidade" de Hércules, lembremos que a mesma função retórica e narrativa é desempenhada com igual graça por outros personagens voltaireanos estranhos ao Novo Mundo: Zadig e Memnon vêm do Oriente, Cândido da Vestfália e Micrômegas da estrela Sirius.

\section{II}

Não era de então (1767) que a filosofia francesa vinha se apropriando de tal tipo de personagens com fins retórico-dialéticos. Antes do século XVIII, Montaigne é certamente a figura mais conhecida, e um rápido exame de dois textos seus pode ser iluminador de toda a tradição posterior. No ensaio Dos Canibais
(Ensaios I, 31), ele se dedicava longamente a expor um painel da vida selvagem, cujos desvios em relação à norma franco-católica pareciam perfeitamente justificados pela diversidade do ambiente, a simplicidade da constituição física e a proximidade à natureza: "Ora, penso (...) que não há nada de bárbaro ou de selvagem nessa nação (...) a não ser porque cada qual chama de barbárie o que não faz parte de seus hábitos. (...) Eles são selvagens no mesmo sentido em que chamamos de selvagens os frutos que a natureza, por si só e em seu curso ordinário, produz. Nestes, são vívidas e vigorosas as verdadeiras e mais úteis e naturais virtudes e propriedades, que já abastardamos nos outros..." (MONTAIGNE 1937, p. 131). Mesmo o hábito inconveniente do canibalismo é relativizado por uma comparação com os morticínios organizados e em massa da guerra moderna (Montaigne escrevia na década de 1570). O final do ensaio é dedicado a uma anedota sobre três selvagens que, trazidos da França Antártica/Brasil a Rouen, resumem em três perguntas suas impressões de viagem:

"Disseram que, em primeiro lugar, achavam muito estranho que tantos homens adultos, de barba, fortes e armados, que estavam ao redor do rei (é verossímil que falassem dos suíços da guarda) se rebaixassem a obedecer a uma criança e não escolhessem algum deles para comandar; em segundo lugar (...) que tinham percebido que havia entre nós homens gordos e abarrotados de toda espécie de mercadoria, e que suas metades [os pobres emagrecidos] andavam mendigando a suas portas, magros de fome e de pobreza; e achavam estranho que essas metades tão necessitadas pudessem sofrer uma tal injustiça sem que se lançassem contra os outros ou ateassem fogo a suas casas." (MONTAIGNE 1937, pp. 221-222)

Depois de haverem destronado o rei e atacado a propriedade, os selvagens teriam feito mais uma observação: "j'ay perdu la 
troisiesme, et en suis bien marry" ("perdi a terceira, e lamento muito"), diz Montaigne, talvez temeroso de ofender o clero, depois de haver escandalizado o Primeiro e o Terceiro Estados. O ensaio de Montaigne parece distanciar-se do conto de Voltaire ao apresentar os hábitos e costumes indígenas como parte de uma ordem social efetivamente existente, organizada e alternativa. Mais que emprestar seu belo porte e sua desenvoltura ao andamento de uma narrativa cômica, seus selvagens carregam uma certa aura de autonomia moral e cultural, que quase os faz tomar a palavra na anedota das três perguntas. A essa aura de autonomia vem se somar, sem sufocar o primeiro aspecto, a tradição dos tópoi utópicos da idade do ouro e do locus amoenus, de origem clássica e cristã, que percorrem todo o ensaio; não mais distanciado no tempo e por ele tornado inatingível, mas sim distanciado no espaço apenas, e logo subitamente posto ao alcance do leitor, o Paraíso Terrenal americano tem sua força ressaltada (ELLIOTT 1992, p. 25).

Mas não há porque exagerar o teor subversivo de Montaigne, atribuindo-lhe um desejo irrestrito de reforma social. O fecho humorístico do mesmo ensaio é uma chapelada ao leitor francês seu contemporâneo e um alerta elíptico a esse viés de leitura: "Tudo isso não é nada mal: mas eles não usam calças!" (MONTAIGNE 1937, p. 222). Para compreender a significação da piada final, podemos recorrer ao ensaio "Dos costumes e da inconveniência de mudar sem maiores cuidados as leis em vigor". Também nesse texto encontramos o motivo do relativismo, introduzido através de um ponto de vista estrangeiro após uma digressão sobre o efeito de embotamento que o hábito exerce sobre a razão: "Os bárbaros não nos parecem mais maravilhosos do que nós a eles; coisa que todos concederiam se, após haverem percorrido estes novos exemplos, soubessem atentar para os nossos próprios [exemplos] e considerá-los sobriamente"
(MONTAIGNE 1937, p. 124). O resultado "teórico" do exame da questão é perceber a falta de fundamentos racionais para os costumes de cada sociedade e assim desvendar a "naturalidade" dos costumes enquanto criação social: "Mas o principal efeito de sua força [do costume] é o de tomar-nos e ocuparnos a tal ponto que mal está a nosso alcance livrarmo-nos de suas garras e voltar a nós mesmos, para investigar e meditar seus mandamentos (...) daí pensarmos que tudo o que está fora dos eixos do costume está fora dos eixos da razão" (MONTAIGNE 1937, p. 128). Mas não está implicada aí a conseqüência prática de que devamos lançar-nos à reforma geral das leis, e o ensaio segue com uma exortação à prudência política: as conseqüências desastrosas da ruína do "edifício dos usos e costumes" de uma nação, produzida por uma inovação impensada, em muito ultrapassa os beneficios resultantes; e o exemplo do reformador que se levanta contra as leis instituídas incita os iníquos à desobediência, baseados em seu juízo privado: "pois quem se põe a decidir e a mudar, usurpa a autoridade de julgar, e deve ser capaz de exibir o erro do que elimina e o bem do que introduz" (MONTAIGNE 1937, p. 134). Antes sujeitar-se aos usos locais e sofrer apenas em si mesmo a injustiça do que arriscar-se a estendê-la sobre todos. Mas, numa última mudança de perspectiva, essa regra de prudência, distante de um imperativo categórico, não exclui a obediência a leis novas que consigam se implantar, e nem mesmo a intervenção ativa quando está em jogo a salvação da comunidade política (MONTAIGNE 1937, pp. 135-6).

Se estamos corretos ao afirmar que a força de atração da imagem utópica de Dos Canibais é temperada pelos requisitos da prudência, deveremos reavaliar seu alcance retórico-dialético no debate filosófico e no embate de culturas. Não é difícil mencionar ao menos um antecedente filosófico de utilização dos mesmos tópicos retóricos da vari- 
edade de culturas para fins de discussão ética. Na qualidade de um dos primeiros protagonistas do "renascimento do ceticismo grego no século XVI" que se segue à "crise intelectual da Reforma" (POPKIN 1979, caps. 1 e 2), Montaigne estava certamente familiarizado com a suma do pirronismo antigo, as Hipotiposes Pirronianas de Sexto Empírico. Sem querer entrar em detalhes, recordemos que, em oposição às filosofias dogmáticas antigas, o pirronismo pretende ser não uma theoría, mas uma agoge, um "procedimento" ou uma "capacidade" de pesquisa e discussão que se limita a apresentar as anomalias - dificuldades, divergências ou contradições - que encontra nos corpos conceituais do dogmatismo. Essa experiência pessoal das contradições nas coisas, nos homens e nas doutrinas deve levar o cético à epoche, à suspensão do juízo quanto à "objetividade" última das opiniões dogmáticas, sejam estas dẹ origem filosófica ou não (SEXTO EMPÍRICO 1976, n 1-35). Assim, percebemos logo a dupla face do ceticismo pirrônico: por um lado uma filosofia baseada na experiência "meramente" pessoal do fenômeno ("o que aparece"), distinta de qualquer espécie de contemplação, e, por outro lado, uma prática de discussão, cujo lugar por excelência é o confronto retórico-dialético (ainda que não à maneira dos sofistas). O máximo de sistematização que o pirronismo se pode permitir é a compilação de vias argumentativas privilegiadas, de caráter prático semelhante ao das regras de prudência, particularmente capazes de embaraçar o dogmático e levar o cético à suspensão do juízo; entre essas vias, destacam-se os dez modos de Enesidemo (SEXTO EMPÍRICO 1976, $\left.n^{\circ} 36-163\right)$ e, para nossos fins, o modo décimo, "o qual lida principalmente com a ética, baseando-se em regras de conduta, hábitos, leis, crenças mitológicas e concepções dogmáticas" (SEXTO EMPÍRICO 1976, $\mathrm{n}^{\circ}$ 145). Trata-se aí de examinar as crenças dogmáticas sobre a "verdade" ou a "universalidade" dos preceitos éticos, isto é, trata-se de opor dificuldades à pretensão de que tal ou qual preceito ou modo de vida seja o único realmente bom ou aceitável ou racional. O procedimento é razoavelmente simples, e consiste em arrolar crenças éticas divergentes - "anômalas" - a respeito de uma mesma questão, contrastando não tanto o conteúdo de cada qual, quanto as pretensões exclusivistas de cada uma delas: "alguns etíopes tatuam seus filhos, mas nós não o fazemos; e enquanto os persas consideram decoroso trajar um vestido tingido em cores brilhantes e caindo até os pés, nós o consideramos indecoroso (...)" (SEXTO EMPÍRICO 1976, nº 148).

Ao cético interessa pouco tentar anular ou refutar os conteúdos fenomênicos das crenças e assim envolver-se em uma discussão a respeito dos méritos da moda persa ou grega: "nossa dúvida não se refere ao fenômeno em si mesmo, mas ao que se afirma sobre o fenômeno - o que é diferente de questionar o próprio fenômeno. Por exemplo, o mel parece-nos doce (e isto concedemos, pois percebemos a doçura por nossos sentidos), mas saber se o mel é doce em sua essência é objeto de dúvida para nós, uma vez que não se trata mais de um fenômeno, mas de um juízo sobre o fenômeno" (SEXTO EMPÍRICO 1976, n $\left.{ }^{\circ} 19-20\right)$. Como age então o cético, desprovido que está de uma doutrina ética pela qual regrar suas ações? Vendo que, mesmo que o desejasse, não seria capaz de permanecer inativo, e percebendo que não tem como nem por que não aceitar (não-dogmaticamente) "o que aparece", o cético encontra um critério quádruplo de ação: a condução da natureza, a força das paixões, a instrução nas várias artes e as leis e costumes da nação onde se vive (SEXTO EMPÍRICO 1976, $\mathrm{n}^{\circ}$ 23-4). A dúvida cética quanto aos fundamentos racionais das leis e costumes não leva a uma atitude de subversão radical, pois 
também esta exigiria alguma espécie de justificação racional para a nova ordem. O efeito ético-político mais provável é uma atitude de tolerância frente ao desvio da norma corrente, ao lado de uma adesão moderada a esta última. Não é difícil reencontrar a mesma atitude geral nos ensaios de Montaigne, para não falar do gosto do autor por catálogos de hábitos divergentes ou abertamente conflitantes, que repetem, no detalhe estilístico, a forma básica da argumentação pirrônica.

\section{III}

A partir de Montaigne, esse lugar retóricodialético do selvagem e do estrangeiro fez fortuna na literatura filosófica francesa. Assim como os tupinambás de Montaigne muito mais, ou menos, do que objeto de uma consideração antropológica - prestavam-se à refutação dos falsos universalismos e da intolerância religiosa, Diderot contará com a colaboração taitiana para realizar a mesma tarefa, no seu Suplemento à Viagem de Bougainville (1772). Encontramos aí a mesma combinação de imagem onírico-utópica de uma civilização alternativa com uma exortação à prudência política que já havíamos encontrado nos Essais, e em termos que parecem retirados a eles: "Falaremos contra as leis insensatas até que sejam reformadas; e, entrementes, nós nos submeteremos a elas. Aquele que, por sua autoridade privada, infringe uma lei má, autoriza a qualquer outro a infringir as boas. (...) Imitemos o bom capelão, monge em França, selvagem no Taiti” (DIDEROT 1979, p. 157). Mas encontramos ademais o mesmo caráter factício do Ingênuo de Voltaire, que torna explícitas as regras da mascarada: o Ancião que discursa e invectiva contra os europeus não fica em nada a dever a Cícero, e sabe muito bem de sua condição de selvagem inocente ("Somos inocentes, somos felizes") e Oru está tão a par dos termos-chave do debate político e moral europeu quanto Hércules estava ("Esses preceitos singulares, eu os acho opostos à natureza e contrários à razão..."); a ingenuidade de suas perguntas serve apenas para constranger o capelão a respostas de péquebrado. Diderot não deixa de incluir observações irônicas sobre o próprio texto que pretende fazer passar por autêntico: "O discurso me parece veemente; mas através não sei que de abrupto e selvagem, parece-me reencontrar nele idéias e construções européias" (DIDEROT 1979, pp. 139, 143 e 141).

Com os devidos reparos, podemos igualmente indicar um ponto comum à técnica argumentativa do cético e à técnica narrativa do Voltaire contista e propagandista das Luzes. Releiamos os verbetes do Dicionário Filosófico sobre a verdade revelada dos Evangelhos, onde se acumulam as anomalias cronológicas e doutrinárias das Sagradas Escrituras, ou então o trecho da Carta Inglesa VI analisado por Auerbach, onde se contrapõem a fraternidade universal efetiva que o comércio entre nações e credos propicia ("como se pertencessem todos à mesma religião") e, do outro lado, o particularismo sectário das várias e pretensas religiões universais, que separam os homens; ou vejamos ainda a rápida anotação do autor à batalha (cette boucherie hérö̈que) do terceiro capítulo de Cândido: "Por fim, enquanto os dois reis mandavam cantar os Te Deum, cada um em seu acampamento, ele [Cândido] decidiu irse meditar alhures sobre os efeitos e as causas" [183]. Uma pincelada basta para desmascarar o ridículo da noção de guerra santa. Digamos então que o que era modo argumentativo no ceticismo torna-se artificio cômico nas mãos de Voltaire. É claro que essa transição do campo filosófico para o da literatura cômica não se dá sem transformações profundas. Vimos que o efeito certeiro 
da sátira voltaireana depende de uma certa sensibilidade instantânea, compartilhada por autor e leitor, que logo produz o efeito retórico almejado - o ridículo.

Ora, esse cânon, Voltaire certamente não o encontrou nas obras de Sexto Empírico ou Montaigne, que não têm nenhum conceito de natureza ou de bom-senso natural a que recorrer. Voltaire é um propagandista das Luzes, e mesmo quando aplica explicitamente uma técnica argumentativa cética, não está interessado em chegar a uma epoche, mas em preparar os espíritos de possíveis conversos: "Sois maometanos, logo há pessoas que o não são, logo pode acontecer que não estejais dentro da razão"; seus escritos estão recheados de uma confiança numa razão natural que, não fosse pela força das superstições e da Infame onipresente, ordenaria a seu gosto as relações humanas e promoveria o progresso do espírito: "Não há seitas em geometria; ninguém se refere a euclidianos, a arquimedianos"; [lei natural é] "o instinto que nos faz sentir a justiça"; "Juntai de um extremo da terra ao outro os simples e tranqüilos agricultores: (...) numa hora farão trinta leis desta espécie, todas úteis ao gênero humano" (VOLTAIRE 1988, verbetes "Seitas", "Lei Natural" e "Das Leis").

Podemos enxergar melhor agora a conexão entre as opções estéticas e ideológicas mais gerais do Voltaire narrador: seus contos participam daquela modalidade da literatura cômica voltada para a produção do ridículo a partir do ponto de vista de um senso comum previamente assumido. Em sua Anatomia da Crítica, N.Frye caracterizou o gênero como "sátira de norma baixa", que "pode ser chamada a forma do ingénu, de acordo com o diálogo de Voltaire desse título. Neste, um estranho à sociedade, no caso um índio americano, é a norma baixa: não tem opiniões dogmáticas próprias, mas não admite que nenhuma das premissas que fazem os absurdos da sociedade pareça lógica aos que se acostumaram com elas. Ele é realmente uma figura pastoral e, como a pastoral, forma adequada à sátira, contrasta um grupo de critérios relativamente simples com as complexas racionalizações da sociedade" (FRYE s.d., p. 228). Não é difícil perceber, por trás do ritmo acelerado da narrativa de aventuras, a intenção de não deixar nenhum tema controverso de fora do texto; contraprova disso é a facilidade que tivemos para comparar trechos de L'Ingénu a passagens de obras não-narrativas de Voltaire. Ora, isso revela, ao lado da perícia narrativa do autor, o pendor temático (FRYE s.d., pp. 57-59) da obra, que nos faz perguntar, no último parágrafo, pela melhor interpretação do conjunto do relato: a de Gordon (um otimismo mascarado) ou a do Ingênuo (a essa altura, para pouca surpresa do leitor, devidamente socializado sob forma de philosophe). É pela mesma via que se explica melhor a dualidade de ritmos narrativos que já mencionamos brevemente: a oscilação entre as aventuras iniciais e a heure creuse narrativa entendese agora como dualidade de aspectos narrativos e temáticos, sob relativa égide deste último; daí também que Frye não hesite em chamar o conto de diálogo - gênero temático por excelência.

Mas é claro que essa opção apresenta perigos fáceis de perceber. Assentado que está no curso corrente de certas opiniões, cuja aceitação é prévia à própria narração, o conto filosófico pode pagar o riso fácil com a superficialidade dessas opiniões. O consenso subjacente pode revelar-se terrivelmente estreito e discriminador para quem não pertença à coterie do autor; para não mencionar o fato de que a arma tem dois gumes, e pode ser fácil e legitimamente dirigida contra o partido filosófico. Deixando de lado a tragédia que atinge a bela St. Yves, como não sentir alguma decepção com o destino final, "integrado", de Hércules, o Ingênuo? Constatemos agora, à diferença de Montaigne e Diderot, a ausência de imagens utópicas em 
torno dos novos mundos descobertos, como que deixando entrever certa estreiteza da visão de mundo voltaireana. A etiqueta cortesão-iluminista deixa pouco lugar à promessa de diversidade que o selvagem poderia ter, e o pacto entre o autor e o selvagem inquiridor ganha certo ar de condescendência, já que se dá indiscutivelmente em termos (ELIAS 1992, cap. VIII). Por uma ironia da história, esse traço de condescendência arrogante aproxima Voltaire de um membro daquela infame corporação, o padre Bartolomé de Las Casas, o evangelizador "humanitário" das Américas; como anota Elliott: "a primeira geração de missionários (...) supunha que suas mentes [dos selvagens] eram, nas palavras de Las Casas, tablas rasas sobre as quais a fé poderia ser facilmente inscrita" (ELLIOTT 1992, p. 33) nosso autor não teria assinado em baixo, fossem outros os tempos, a fé e a corporação? Falta a Voltaire dar um passo a mais na visão irônica, além dos limites da propaganda, para, nas palavras de Frye, passar à fase seguinte da sátira, para perceber que "também o senso comum tem certos dogmas implícitos" (FRYE s.d., p. 230).

Se esta expectativa parecer anacrônica a alguns, cabe lembrar o contra-exemplo mais famoso, isto é, o tom agônico que toma conta da obra de Rousseau quando se trata de expressar o estado de natureza, que talvez não tenha existido jamais... Rousseau alcança uma escrita paradoxal e uma pungência utópica em sua tentativa de imaginar, em primeiro lugar, a vida humana para além não só da sociedade francesa, mas também de qualquer organização social estável e, em segundo lugar, a passagem tão dificilmente compreensível de um estado a outro. Os exemplos, encontradiços no Discurso sobre a Origem e os Fundamentos da Desigualdade entre os Homens, são muitos e bem conheci- dos; cito três apenas: “...só me falta considerar e interligar os vários acasos que puderam aperfeiçoar a razão humana, deteriorando a espécie"; "um sentimento terno e doce insinua-se na alma humana e, face à menor oposição, torna-se um furor impetuoso: o ciúme desperta junto com o amor; a Discórdia triunfa e a mais doce das paixões recebe sacrifícios de sangue humano"; "os homens, gozando de grande ócio, empregaram-no em proporcionar a si mesmos várias espécies de comodidades desconhecidas de seus Pais; e foi este o primeiro jugo que inadvertidamente se impuseram" (ROUSSEAU 1964, pp. 162,169 e 168).

Tudo isso afasta o conto filosófico voltaireano da estética do romance oitocentista; o que lhe sobra em desenvoltura, falta-lhe em paciência para acompanhar o desenvolvimento interior das personagens, bem como para confiar a estas - e não a uma sucessão de acasos cômicos ou aventurescos - a condução do fio narrativo e o destino das idéias em campo. Outro é o seu universo estético, e dentro dos limites deste, Voltaire atinge um grau de lepidez e graça dificilmente igualáveis. Schiller criticava justamente essa falta de compromisso: "Em toda parte, aliás, muito pouca seriedade serve de fundamento a seu escárnio, e isso torna suspeita, com justiça, a sua vocação poética. (...) Nenhum Ideal se mostra sob aquele invólucro de ar e quase nada de absolutamente firme naquele moto-contínuo" (SCHILLER 1991, p. 69) imagine-se o tédio profundo que uma hipotética versão schilleriana do Cândido provocaria! Vale mais pensar que, a despeito das amarras ideológicas (ou do "Ideal") que o conto voltaireano de fato tem, devemos ser gratos a Voltaire pela relativa parcimônia de suas declarações explícitas de princípios e pela agilidade que soube imprimir à exibição do espetáculo do ridículo. 
Cadernos de Campo, São Paulo, $n^{\circ}$ 4, p. 79-90, 1994.

\section{Bibliografia}

Auerbach, Erich.

1988 Mimesis. Berna, Francke Verlag.

Booth, Wayne.

1974 A Rhetoric of Irony. Chicago/London, University of Chicago Press.

Diderot, Denis.

1979 Suplemento à viagem de Bougainville, in Diderot. São Paulo, Abril, trad. Marilena Chauí.

Elias, Norbert.

1992 Die höfische Gesellschaft. Frankfurt a/M, Suhrkamp.

Elliott, J.H.

1992 The Old World and the New, 1492-1650. Cambridge, Cambridge UP.

Frye, Northrop.

s.d. Anatomia da Crítica. São Paulo, Cultrix.

Montaigne, Michel de.

1937 Essais, ed. A. Thibaudet. Paris, Gallimard/Pléiade.

Popkin, Richard.

1979 The History of Scepticism from Erasmus to Spinoza. Berkeley/Los Angeles/London, University of California Press.

Rousseau, Jean-Jacques.

1964 Discours sur l'Origine et les Fondements de l'Inégalité Parmi les Hommes, in Oeuvres, ed. B.Gagnebin e M.Raymond. Paris, Gallimard-Pléiade.

Schiller, Friedrich.

1991 Poesia Ingênua e Sentimental, São Paulo, Iluminuras, trad. Márcio Suzuki.

Sexto Empírico.

1976 Outlines of Pyrrhonism. Londres/Cambridge, Mass., Heinemann/Harvard UP [Loeb Classical Library].

Starobinski, Jean.

1966 "Le Fusil à deux coups de Voltaire", in Révue de Métaphysique et de Morale, julho/setembro.

Voltaire.

1966 Romans et Contes, ed. R.Pomeau. Paris, Flammarion.

1979 Dicionário Filosófico, in Voltaire. São Paulo, Abril, trad. M.Chauí et alii.

1939 Entretien d'un Sauvage et d'un Bachelier, in Dialogues et Anecdotes Philosophiques, ed. R.Naves. Paris, Garnier.

Watt, Ian.

1990 A Ascensão do Romance. São Paulo, Cia. das Letras. 